\title{
Basal crevasses in Larsen C Ice Shelf and implications for their global abundance
}

\author{
A. Luckman ${ }^{1}$, D. Jansen ${ }^{1}$, B. Kulessa ${ }^{1}$, E. C. King ${ }^{2}$, P. Sammonds ${ }^{3}$, and D. I. Benn ${ }^{4,5}$ \\ ${ }^{1}$ College of Science, Swansea University, UK \\ ${ }^{2}$ British Antarctic Survey, High Cross, Cambridge, UK \\ ${ }^{3}$ Department of Earth Sciences, University College London, UK \\ ${ }^{4}$ University Centre in Svalbard, P.O. Box 156, 9171, Longyearbyen, Norway \\ ${ }^{5}$ Department of Geography, University of St. Andrews, UK
}

Correspondence to: A. Luckman (a.luckman@swansea.ac.uk)

Received: 6 July 2011 - Published in The Cryosphere Discuss.: 28 July 2011

Revised: 15 December 2011 - Accepted: 4 January 2012 - Published: 24 January 2012

\begin{abstract}
Basal crevasses extend upwards from the base of ice bodies and can penetrate more than halfway through the ice column under conditions found commonly on ice shelves. As a result, they may locally modify the exchange of mass and energy between ice shelf and ocean, and by altering the shelf's mechanical properties could play a fundamental role in ice shelf stability. Although early studies revealed that such features may be abundant on Antarctic ice shelves, their geometrical properties and spatial distribution has gained little attention. We investigate basal crevasses in Larsen C Ice Shelf using field radar survey, remote sensing and numerical modelling. We demonstrate that a group of features visible in MODIS imagery are the surface expressions of basal crevasses in the form of surface troughs, and find that basal crevasses can be generated as a result of stresses well downstream of the grounding line. We show that linear elastic fracture mechanics modelling is a good predictor of basal crevasse penetration height where stresses are predominantly tensile, and that measured surface trough depth does not always reflect this height, probably because of snow accumulation in the trough, marine ice accretion in the crevasse, or stress bridging from the surrounding ice. We conclude that all features visible in MODIS imagery of ice shelves and previously labelled simply as "crevasses", where they are not full thickness rifts, must be basal crevasse troughs, highlighting a fundamental structural property of many ice shelves that may have been previously overlooked.
\end{abstract}

\section{Introduction}

Basal (or bottom) crevasses are fractures that extend upwards from the bottom of ice bodies (Jezek, 1984; van der Veen, 1998a). They differ from surface crevasses in their direction of opening and in that they have the assistance of basal water at pressure to promote their initiation and propagation. The radar signatures of basal crevasses up to hundreds of meters in height have been identified in (among others) the Ross Ice Shelf (Jezek et al., 1979; Jezek and Bentley, 1983), a large tabular iceberg calved from the same (Peters et al., 2007), and the Fimbul Ice Shelf (Humbert and Steinhage, 2011). Basal crevasses have also been observed in glacier ice where subglacial water pressure is high enough (Christoffersen et al., 2005, Harper et al., 2010). In early radar surveys the signatures of basal crevasses were detected often enough to lead Shabtaie and Bentle (1982) to suggest that such crevasses are likely to be "abundant" in Antarctic ice shelves.

Basal crevasses have, however, received little attention in the recent literature, although we are aware of a similar study to this one (McGrath et al., 2012). Despite the current focus on ice shelves and their disintegration, few studies in the last decade make direct reference to such features, which is at odds with their previously inferred abundance and their potential impact on both the ice and the ocean cavity beneath. By increasing the area of interface between ice and water, basal crevasses may enable heat exchange with the ocean deep inside the ice column where the ice would otherwise be well insulated from external heat sources (Hellmer 
and Jacobs, 1992). This increased area of interface may also moderate the exchange of mass with the ocean through melting and refreezing. Basal crevasses will additionally modify local stresses in the ice, thereby potentially playing a key part in ice shelf stability (Jezek, 1984; Shepherd et al., 2003). It is therefore important to understand where and how frequently they occur.

In this paper we use ground penetrating radar (GPR), global positioning system (GPS) and remote sensing to investigate features in the Larsen $C$ Ice Shelf that are visible in the MODIS (Moderate resolution imaging spectroradiometer) mosaic of Antarctica (MOA) (Fig. 1, Haran et al., 2005). We differentiate between surface and basal crevasses in terms of their GPR and satellite image signatures. In the light of these observations we consider implications for the abundance and potential impact of basal crevasses elsewhere in the ice shelf and beyond. We also test the ability of the linear elastic fracture mechanics (LEFM) approach to predict the penetration height of basal crevasses for which we have field data.

\section{GPR observations from Larsen C Ice Shelf}

We focus on two groups of features near the Joerg Peninsula (Fig. 2a and b) which are visible in commonly-used satellite images (Fig. 1), and which have previously been discussed simply as "crevasses" (Glasser et al., 2009). These are aligned approximately perpendicular to the ice flow direction and form part of two quasi-periodic series of features which start near the grounding line and end at the calving front. These features are defined by their planimetric dimensions of width (the smaller dimension) and their length (the longer dimension). The first series (Fig. 2a, referred to here as Series 1) originates close to the grounding line, and is characterised by features that are $\sim 4 \mathrm{~km}$ in length, are perpendicular to the flow direction, occur on ice that is $\sim 350 \mathrm{~m}$ thick and have a regular spacing along flow of $\sim 1 \mathrm{~km}$. Taking into account flow speeds at this location (Jansen et al., 2010), this implies that they are generated approximately every $5 \mathrm{yr}$. We highlight two features in this series for later attention and refer to them as "S1C1" (series one, crevasse one, etc.) and "S1C2" (Fig. 2a). The second series of features (Fig. 2b, Series 2) are $\sim 10 \mathrm{~km}$ long and are $\sim 30 \mathrm{~km}$ from the grounding line at their closest and are found on ic $\sim 320 \mathrm{~m}$ thick. The feature in this series nearest the grounding line (and we assume therefore to be the most recent in origin) we refer to as "S2C1" and the next one downstream (and therefore assumed older) as "S2C2". Although their periodicity is less regular compared to that of Series 1 , the most recently developed three features in Series 2 have a spacing of $\sim 5 \mathrm{~km}$ equivalent to a creation every $14 \mathrm{yr}$ at a flow speed of approx. $360 \mathrm{~m} \mathrm{a}^{-1}$.

During November and December 2009 we carried out a field campaign using GPR and dGPS (differential GPS) to
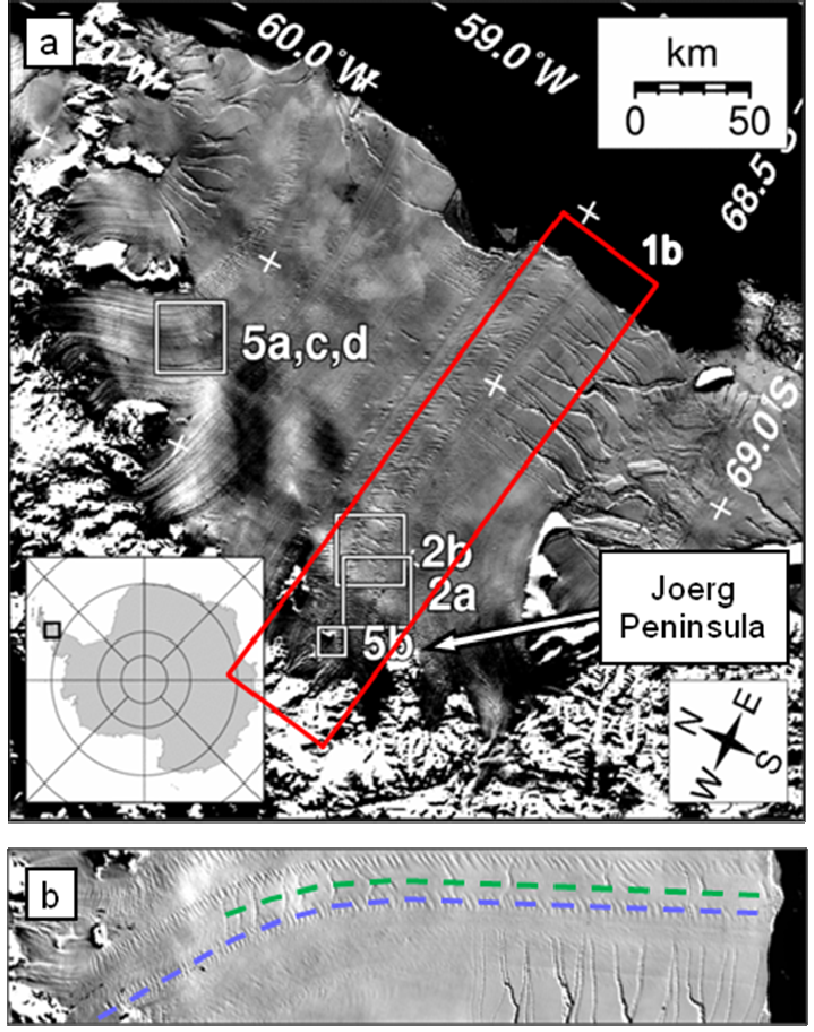

Fig. 1. (a) Location of Larsen C Ice Shelf featuring an extract from MODIS MOA mosaic (2003; Haran et al., 2005). Boxes indicate areas covered by later figures; (b) rotated part of MOA image with dashed lines highlighting the two crevasse series investigated - Series 1 in blue and Series 2 in green.

investigate the structure of the ice shelf in this region including ice heterogeneity, shelf thickness and the signature of marine ice. Several hundreds of line kilometres of commonoffset $50 \mathrm{MHz}$ radar data were acquired using a Pulse-Ekko PE100 GPR system towed behind a snow-scooter. Precise planimetric and height location of the antennas was recorded with a differential Leica System 1200 GPS. The GPS position wass recorded every second and the maximum baseline was $15 \mathrm{~km}$. The GPR surveys were carried out with a sampling interval of $0.8 \mathrm{~ns}$ using 8 stacks. GPR traces were acquired every $3 \mathrm{~s}$ at a towing speed of approximately $5 \mathrm{~km} \mathrm{~h}^{-1}$, yielding a mean trace spacing of $\sim 4.3 \mathrm{~m}$. Here we present $\sim 20 \mathrm{~km}$ of GPR data that cover features of interest in the ice shelf.

The raw GPR data were processed using standard techniques including automatic gain control, band pass filtering, and correction for surface topography as recorded by dGPS. Travel time was converted to depth assuming a radarwave velocity in ice of $0.175 \mathrm{~m} \mathrm{~ns}^{-1}$, a value based on fitting diffraction hyperbolae to data from a common mid-point (CMP) survey carried out on one of the crests between the crevasses on the profile (Fig. 2a). We present the data as 


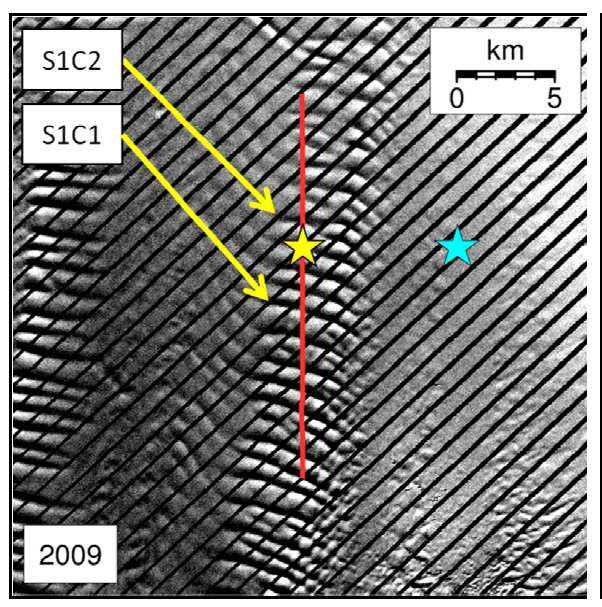

(a)

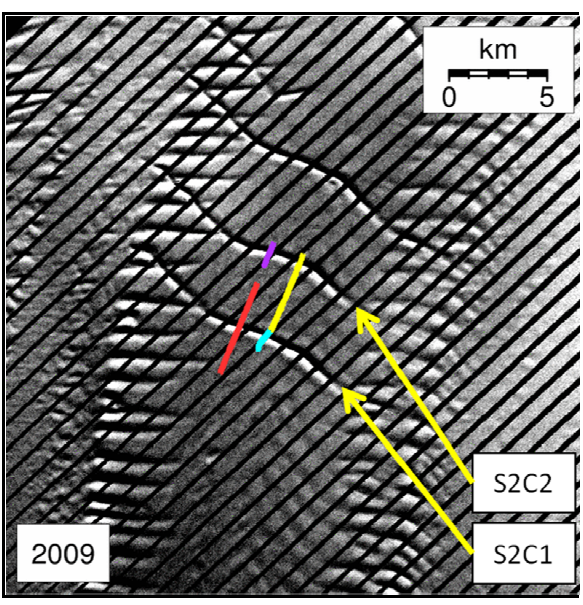

(b)

Fig. 2. Landsat 7 sub-images from the southern end of Larsen C Ice Shelf showing features investigated in 2009 by RES along transects shown in various colours, location of CMP survey (yellow star), and location of GPS base-station (cyan star): (a) Series 1 of closely-space features; (b) Series 2 of widely-spaced features. See Fig. 1 for location within the ice shelf. Black diagonal stripes are due to a well-known Scan Line Correction fault.

un-migrated profiles because features deep in the ice column are more easily identified in printed figures by their characteristic hyperbolic returns.

Figures 3 and 4 show the processed radargrams from profiles over the two series of features. A single profile of GPR data was acquired from Series 1, while from Series 2, four profiles were acquired from $\mathrm{S} 2 \mathrm{C} 1$ and two from $\mathrm{S} 2 \mathrm{C} 2$. All radargrams collected from Series 2 are presented to demonstrate the repeatability of the observations.

Following previous authors (e.g. Jezek and Bentley, 1983), we interpret these data as exhibiting the signatures of basal crevasses. The key characteristics of basal crevasses in GPR data are the highly uneven basal return (in which the basal openings are usually evident), and the reflection from the crevasse tips (emphasized here by presenting un-migrated data). The crevasse tips are clearer for Series 2 (Figs. 2b, 4) than for Series 1 features (Figs. 2a, 3). Our GPR profiles were collected perpendicular to the crevasses so the typical basal width of Series 1 crevasses appears to be $\sim 400 \mathrm{~m}$. For S2C1 and S2C2 of Series 2, the complex basal echoes do not allow such an estimate to be made. The penetration height of Series 1 crevasses is not generally as clear as Series 2, but $\mathrm{S} 1 \mathrm{C} 1$ and S1C2 tips are visible in the GPR data and these crevasses are chosen for further analysis (Fig. 3). Assuming that these echoes originate from the highest penetration point, the Series 1 crevasse heights are around $100 \mathrm{~m}$ above the base of the ice shelf, which is close to one third of the ice shelf thickness at this location. The penetration height of Series 2 basal crevasses is between $180 \mathrm{~m}$ and $230 \mathrm{~m}$ above the base of the ice shelf, or around two-thirds of the ice thickness. Table 1 gives more precise values for basal crevasse dimensions. In the absence of better error estimates from our own data, we assume that errors in basal crevasses penetration height are proportional to velocity errors from CMP surveys and are therefore $5 \%$ (Barrett et al., 2007).

In addition to the specific characteristics of the basal crevasses, two further aspects of the radargrams (Figs. 3 and 4) are of note. Firstly, hyperbolic radar responses originating near the surface, can be seen on the edges of some of the surface troughs and these are highlighted in Fig. 4. Secondly, the ice shelf surface (as measured by dGPS) has troughs directly over each basal crevasse, and shallow internal layering within the ice follows approximately the profile of these surface troughs. Deeper layers appear to be more deformed downwards above the basal crevasses than is the ice surface, although we should note that this may partly be due to the fact that we have assumed a constant radar velocity despite the varying ice density. For Series 1 basal crevasses, the surface troughs are 5-10 m deep, and for Series 2 they are $\sim 10 \mathrm{~m}$ deep. The widths of these surface troughs are not well defined in either the GPS data or the satellite data as there is no clear break in slope. However, for both crevasse series the apparent surface deformation extends more than $500 \mathrm{~m}$. More precise characteristic measurements of ice thickness, penetration height and trough depth for the four highlighted crevasses are presented in Table 1.

\section{Discussion of GPR observations}

\subsection{Basal crevasses}

We have established that the features visible in MODIS data (Fig. 1), illustrated using Landsat data (Fig. 2) and 
Table 1. Measured and modelled properties of four basal crevasses on Larsen C Ice Shelf with estimates of error.

\begin{tabular}{|c|c|c|c|c|c|c|c|c|}
\hline Crevasse & $\begin{array}{l}\text { Measured deformation } \\
\text { rate (RS) } \\
\pm 0.0005\left[\mathrm{a}^{-1}\right]\end{array}$ & $\begin{array}{l}\text { Ice thickness } \\
\text { (GPR) } \\
\pm 5 \%[\mathrm{~m}]\end{array}$ & $\begin{array}{l}\text { Mean ice Density } \\
\quad(\text { seismics }) \\
\pm 10\left[\mathrm{~kg} \mathrm{~m}^{-3}\right]\end{array}$ & $\begin{array}{c}\text { Measured crevasse } \\
\text { penetration height (GPR) } \\
\pm 5 \%[\mathrm{~m}]\end{array}$ & $\begin{array}{l}\text { Modelled crevasse } \\
\text { penetration height } \\
\quad \pm 10[\mathrm{~m}]\end{array}$ & $\begin{array}{l}\text { Measured surface } \\
\text { trough depth (GPS) } \\
\quad \pm 0.02[\mathrm{~m}]\end{array}$ & $\begin{array}{l}\text { Modelled surface } \\
\text { trough depth } \\
\quad \pm 1[\mathrm{~m}]\end{array}$ & $\begin{array}{l}\text { Measured surface } \\
\text { trough width (GPS) } \\
\quad \pm 10[\mathrm{~m}]\end{array}$ \\
\hline $\mathrm{S} 1 \mathrm{C} 1$ & 0.0055 & 358 & 870 & 108 & 100 & 6.7 & 10.7 & 580 \\
\hline $\mathrm{S} 1 \mathrm{C} 2$ & 0.0055 & 350 & 870 & 119 & 102 & 8.8 & 12.2 & 580 \\
\hline $\mathrm{S} 2 \mathrm{C} 1$ & 0.0086 & 328 & 804 & 217 & 140 & 12.3 & 23.2 & 375 \\
\hline $\mathrm{S} 2 \mathrm{C} 2$ & 0.0086 & 315 & 824 & 180 & 145 & 10.5 & 18.6 & 435 \\
\hline
\end{tabular}

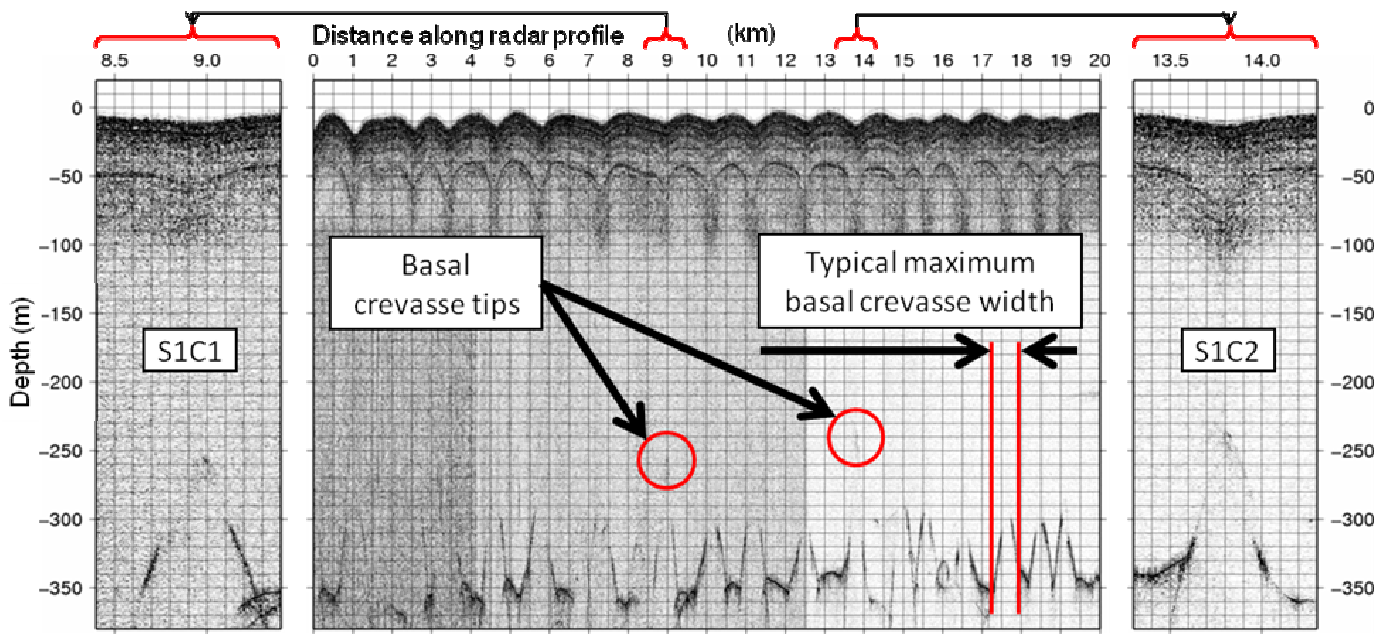

Fig. 3. GPR data from Series 1 crevasses along the transect shown in Fig. $2 \mathrm{a}$ : centre panel is the full $20 \mathrm{~km}$ profile, and right and left-hand panels show enlargement of $\mathrm{S} 1 \mathrm{C} 1$ and $\mathrm{S} 1 \mathrm{C} 2$ for clarity. Ice flow direction is left to right. X and y-axes on different scales: $\mathrm{x}$-dimension assumes one radar pulse every $5 \mathrm{~m}$ of travel and y-dimension assumes a constant velocity in ice of $0.175 \mathrm{~m} \mathrm{~ns}^{-1}$.

investigated using GPR (Figs. 3 and 4) are basal crevasses. In this section we discuss their origin, geometrical characteristics and associated GPR signatures.

The potential for the formation of basal crevasses in ice shelves is well established from a theoretical perspective (e.g. van der Veen, 1998a) as well as from previous radioecho-sounding (RES) observations (e.g. Jezek and Bentley, 1983). The formation of basal crevasses requires tensile deviatoric stresses and basal water pressures at or close to overburden pressure, conditions that occur readily below floating ice shelves and transiently during glacier surges (Weertman, 1980; van der Veen, 1998a; Christoffersen et al., 2005). Basal crevasses may form where the stress intensity exceeds a critical value and, once a critical flaw size is exceeded, are able to grow quickly to their maximum extent. The size of these initial flaws is on the order of a meter and it is likely that such cracks will be found readily in the base of ice shelves, especially near the grounding line (van der Veen, 1998a).

Marine ice might be expected to concentrate in basal crevasses because of the buoyant nature of super-cooled, low salinity source water (Khazendar and Jenkins, 2003), and certain regions of Larsen $C$ Ice Shelf are subject to marine ice accretion (Holland et al., 2009). Outside these regions basal crevasses will continue to creep open through the same stresses that initiated them, and melting of the ice faces in contact with the ocean may enhance this process where the water is sufficiently warm (Jenkins and Doake, 1991), as is believed to be the case for Larsen C Ice Shelf (Shepherd et al., 2003). For crevasse heights of 100-200 $\mathrm{m}$ in Series 1 and 2 , we observe maximum crevasse widths at the ice shelf base of hundreds of meters (Figs. 3 and 4).

Where basal crevasses do not freeze shut again quickly after opening (Weertman, 1980) or fill significantly with marine ice, hydrostatic forces can no longer completely support the ice above them. As a result, the surface of the ice shelf can deform viscously downwards to provide a surface expression of the basal crevasse below in the form of a trough (Shabtaie and Bentley, 1982). This process explains the surface troughs we measured, and also the deformation of internal layers: deeper (older) layers may show more deformation than the surface layers because more recent layers are likely to be subject to uneven accumulation which would tend to favour the trough. The trough widths we observe (Figs. 3 and 4) are consistent with the maximum widths of the basal crevasses below them (hundreds of meters). 


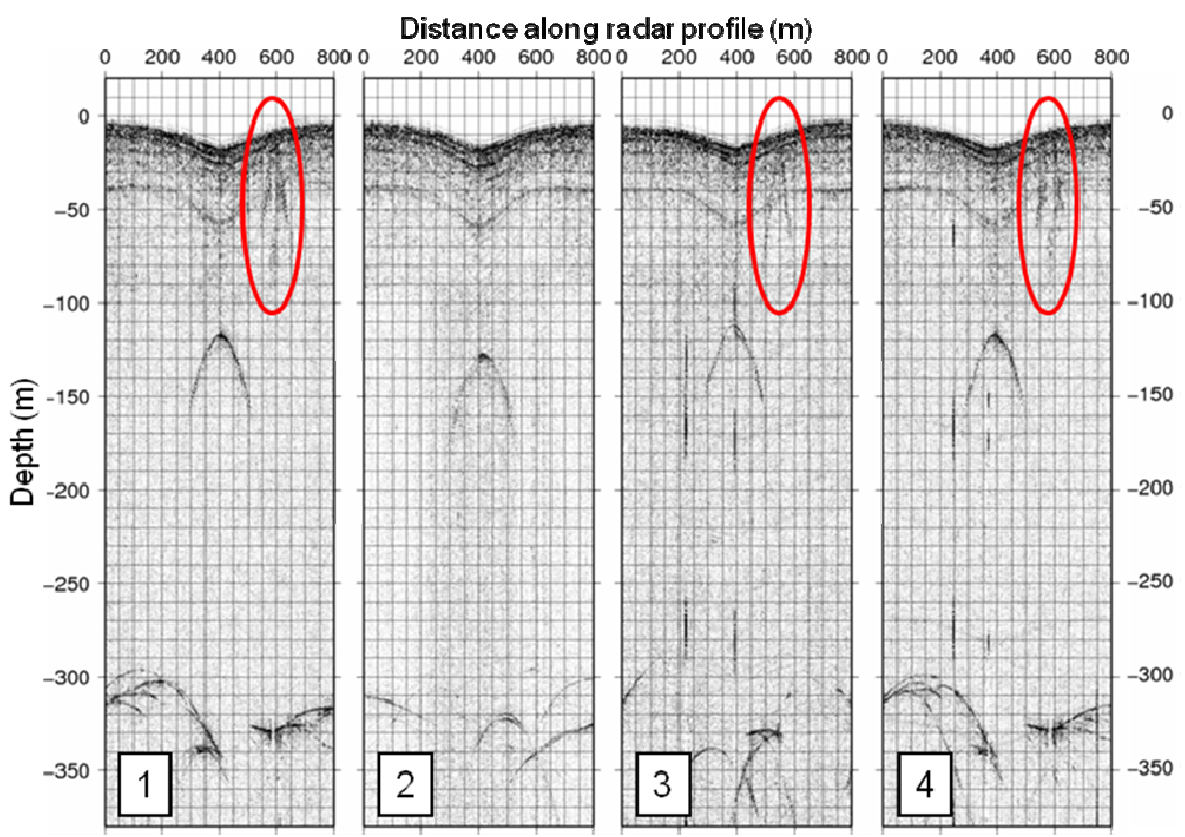

(a) Four passes over S2C1

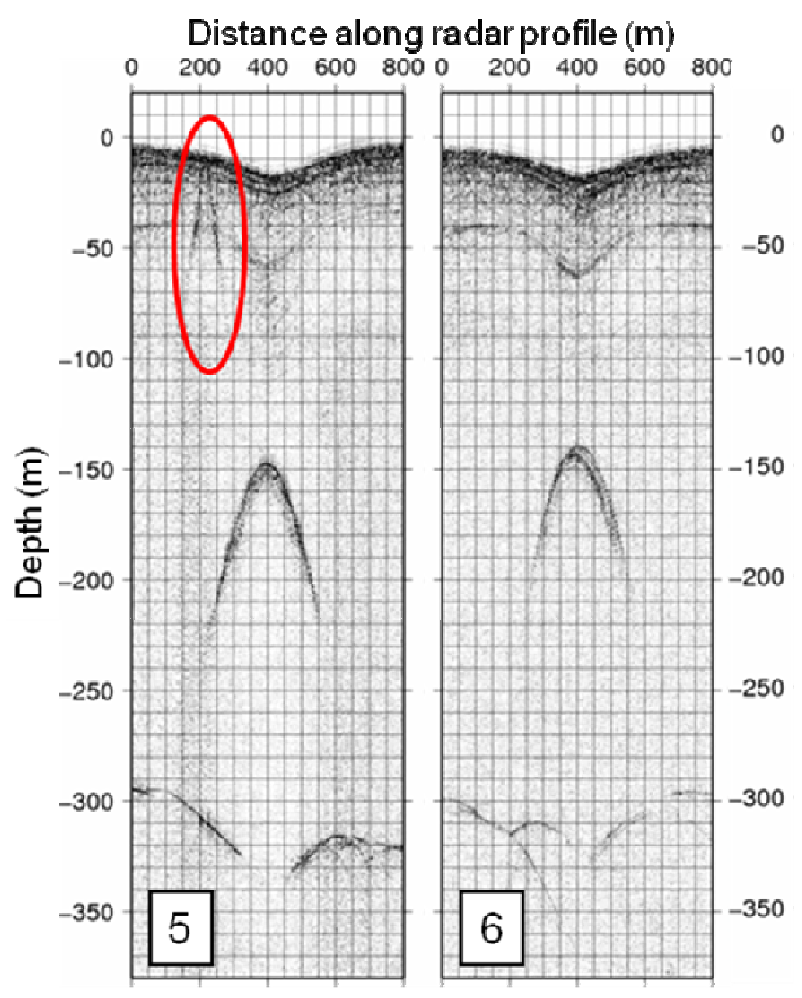

(b) Two passes over S2C2

Fig. 4. Multiple GPR profiles over crevasses $\mathrm{S} 2 \mathrm{C} 1$ and $\mathrm{S} 2 \mathrm{C} 2$ along transects shown in Fig. $2 \mathrm{~b}$. Axes are in meters and not to scale: $\mathrm{x}-$ dimension assumes one radar trace every $4.3 \mathrm{~m}$ of travel and y-dimension assumes a constant velocity in ice of $0.175 \mathrm{~m} \mathrm{~ns}{ }^{-1}$. Multiple passes are illustrated to demonstrate measurement repeatability and correspond to coloured transects in Fig. 2b as follows; 1 and 4 : blue; 2 and 3: red; 5: yellow and 6: purple. Flow direction in each case is left to right. Surface crevasse reflections highlighted in red. 
The depths of surface troughs above basal crevasses are influenced by a number of factors, some of which are not well known for our study. These include the penetration height of the crevasse, the density profile through the ice column, the differential surface accumulation patterns since the trough was formed, how much marine ice has collected within the crevasse, and finally whether there is stress-bridging (otherwise known as flexural stresses) across the crevasse. If we assume no stress bridging, surface accumulation to be homogeneous, ice density to be consistent with that measured elsewhere by CMP survey, and marine ice not to be present, then hydrostatic equilibrium would predict surface trough depths approximately 1.5 times as deep as we measure (Table 1). Therefore not all of these assumptions can be correct and one or more effect must be in operation to limit the crevasse trough depth.

In summary, both series of surface features that we investigated on Larsen $C$ Ice Shelf, and which represent just a few of an extensive series of such features stretching from near the grounding line all the way to the calving margin, can be entirely explained by the presence of basal crevasses. The signatures in satellite imagery of these features are the surface troughs that form above the basal crevasses in response to hydrostatic forces, and which are limited in depth by differential surface or basal accumulation, or by stress bridging.

\subsection{Surface crevasses}

Surface crevasses may be initiated by the same stresses as basal crevasses and may therefore be expected to form in similar parts of an ice shelf (van der Veen, 1998b). Without the influence of water at pressure, however, surface crevasses cannot penetrate nearly as far through the ice column as basal crevasses unless a plentiful source of surface melt-water is invoked (van den Broeke, 2005). One estimate of the typical ratio of surface crevasse penetration depth to basal crevasse penetration height under equivalent stress conditions is around 1:10 (Weertman, 1980). If we make the assumption that basal and surface crevasses have similar width-to-depth aspect ratios, the maximum width of a surface crevasse will therefore be at most $\sim 10 \%$ of that of a basal crevasse in the same part of an ice shelf. This ignores the likelihood of melt widening within a basal crevasse, which would make the ratio of basal to surface crevasse widths still greater. Sustained melt widening in surface crevasses is highly unlikely given the mean air temperatures where ice shelves form. Thus, where the surface expression of a basal crevasse is expected to have a visible width of hundreds of meters, a neighbouring surface crevasse will at most be meters to tens of meters wide. The implications of this difference for their visibility in satellite data is discussed later.

The near-surface hyperbolic radar responses highlighted in Fig. 4 are characteristic of surface crevasses (Woodward and Burke, 2007). Despite their prevalence in our common-offset
GPR data, surface crevasses were only seen occasionally in the field on the down-stream side of basal crevasse troughs. Where they were not obscured by accumulated snow, their width was a few meters and thus consistent with the expected ratio of surface to basal crevasse widths. It is not known whether these surface crevasses were generated at the same time as the basal crevasses as a result of the same stresses that initiated the latter, or during a later period as a result of the local downwards deformation responsible for the formation of the trough.

\section{Satellite observations from Larsen C Ice Shelf}

The widths of the basal crevasse troughs observed in MODIS (Fig. 1) and Landsat (Fig. 2) imagery is entirely consistent with our field data. At the low sun-angles experienced at this latitude, the pattern of reflectance in the satellite images is also consistent with the known depths and shape of the surface troughs. There are no other features in Fig. 2 that cannot be explained by the presence of basal crevasses in this region. Elsewhere on the ice shelf, however, recent satellite images exhibit features that are unlike those we investigated. Figure 5 shows Landsat 7 panchromatic images $(15 \times 15 \mathrm{~m}$ pixels) of an area in the North of Larsen C Ice Shelf containing features that closely match Series 1 crevasses (S1C1 and S1C2) in their size, shape and periodicity ( $\sim 18 \mathrm{yr})$ and we therefore interpret these also as the surface expressions of basal crevasses. Alongside these troughs are much narrower surface features that are only a pixel or two wide, are longer than the surface troughs, but have the same orientation (Fig. 5a). Similar diverse sets of features are also found near the grounding line in the South of Larsen C Ice Shelf (Fig. 5b) and have been noted on the Fimbul Ice Shelf (Humbert and Steinhage, 2011).

Figure 5 also shows that between 1986 and 2010, a new basal crevasse trough formed in this series. Despite a careful inspection of all available images, including US Department of Defence declassified intelligence satellite photography (DISP) from 1963, no such development of new features in crevasse Series 2 was detected.

\section{Discussion of satellite observations}

\subsection{Background}

Surface features on ice shelves have been observed in remotely-sensed images since the earliest satellite missions (e.g. Crabtree and Doake, 1980). Their shape, pattern and development through time have been used to infer ice source, flow direction and speed. A variety of features have been described including "rifts", "flow-lines", "crevasses", "crevasse fields" and "crevasse plumes", and most studies of such features have used data from the Landsat or MODIS 


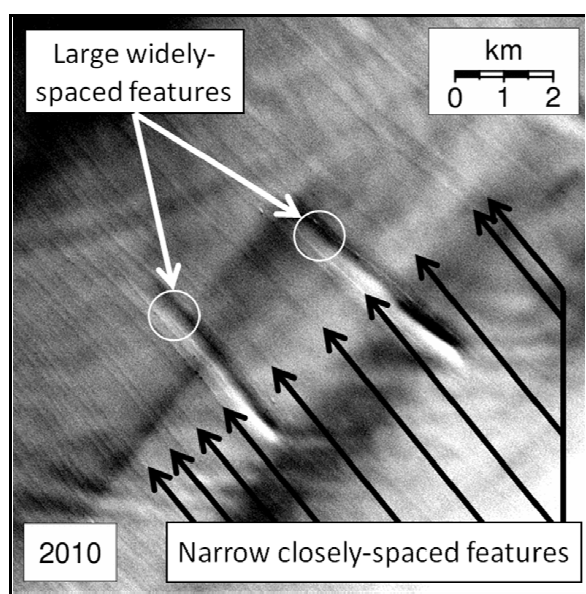

(a)

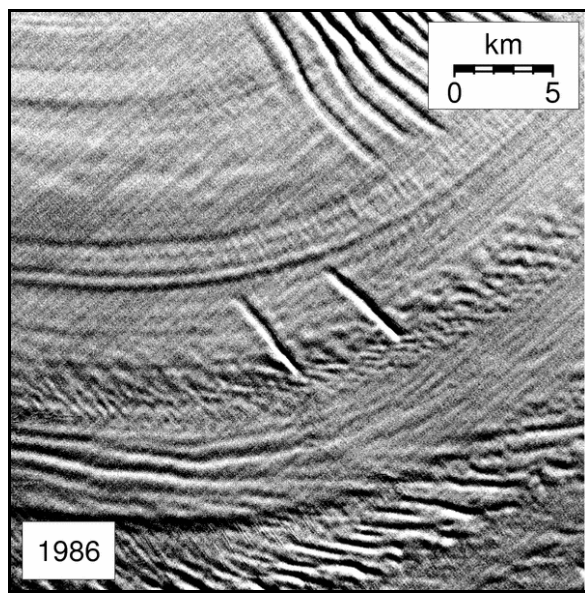

(c)

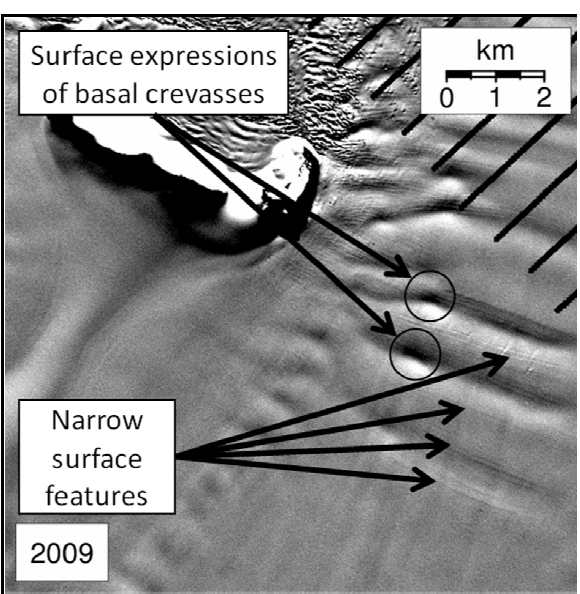

(b)

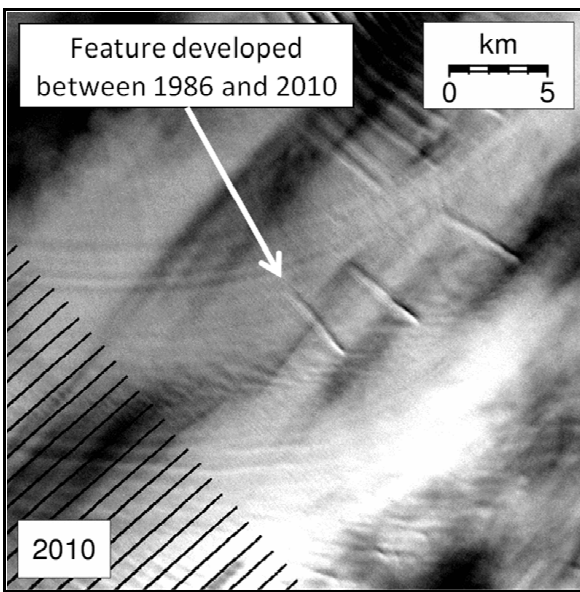

(d)

Fig. 5. Landsat sub-images from parts of Larsen C Ice Shelf indicated in Fig. 1 showing: basal crevasse troughs and adjacent narrow features towards the North (a) and South (b) of the ice shelf; and (c, d) advection of the surface expression of basal crevasses between 1986 and 2010 and development of a further basal crevasse mid-shelf (flow is left to right and the two 1986 features have been advected $\sim 5 \mathrm{~km}$ in this period).

satellite missions (e.g. Skvarca, 1994; Fahnestock et al., 2000; Glasser et al., 2009).

MODIS images provides a pixel size of $250 \mathrm{~m}$. Early Landsat Multi-Spectral Scanner (MSS) images provided a pixel size of $60-80 \mathrm{~m}$ in the visible bands, which was improved to $30 \mathrm{~m}$ through the development of the satellite mission and the launch of new Landsat Thematic Mapper instruments, but it was not until the launch of Landsat 7 in 1999 that data with a $15 \mathrm{~m}$ pixel size was readily available. Pixel size is not equivalent to spatial resolution, but the spatial resolution of these sensors is not significantly different from the spacing of the data grid on which they are distributed. Features smaller than the spatial resolution may be resolved in such images, but only as long as they exhibit adequate radiometric contrast to their background and are sufficiently widely spaced. The various surface features identified in previous ice shelf studies are, of course, formed from the same basic material and therefore cannot be discriminated by any inherent spectral properties. Their contrast is owed entirely to their three-dimensional shape, and the way in which this modifies the reflectance of sunlight that naturally has a low solar azimuth at polar latitudes.

\subsection{Observations}

Considering the spatial resolution of early Landsat and recent MODIS data, and the likely shape and widths of surface crevasses compared to basal crevasses, it is highly unlikely that ice shelf features identified from such satellite data and described as "crevasses" are surface crevasses. For surface 
crevasses only meters wide, detection in data sampled at 60 or $250 \mathrm{~m}$ would require an unreasonable level of contrast given the homogeneity of materials. However, it is conceivable that panchromatic data from Landsat 7 ( $15 \mathrm{~m}$ pixels) could resolve surface crevasses as well as the much wider troughs associated with basal crevasses. The narrow features in Fig. 5a and b, therefore, we interpret as surface crevasses. These were not visible in MODIS or earlier Landsat data of the northern part of Larsen C Ice Shelf, nor were they detected in any Landsat images near basal crevasses in Series 1 or Series 2 (Fig. 2). However, similar narrow features can be seen in Landsat 7 ( $15 \mathrm{~m}$ pixels) images closer to the grounding line in the region of the ice shelf that we surveyed (Fig. 5b).

Finally, if we accept, by similarity of morphology to S2C1 and $\mathrm{S} 2 \mathrm{C} 2$, that the large features in Fig. $5 \mathrm{c}$ and $5 \mathrm{~d}$ are the surface expressions of basal crevasses, then the development of a new feature in this series between 1986 and 2010 is of note. It demonstrates that basal crevasses penetrating up to two-thirds of the way through the ice column may be initiated and propagated due to stresses within the floating part of an ice shelf a considerable distance downstream of the grounding line.

In summary, we have shown that surface crevasses may be observed in Landsat 7 data, but that these are highly unlikely to be the features referred to in many previous papers as "crevasses" as they are too narrow to have been observed in any but the highest spatial resolution satellite data which have only been available since 1999 . We have demonstrated that all of the features observed in satellite images that we investigated by GPR may be explained by the presence of basal crevasses and their surface expressions. We have established that no feature in MODIS or early Landsat data is likely simply to be a surface crevasse. By elimination, such features and groups of features must therefore be either the surface expressions of basal crevasses, or rifts which propagate laterally and penetrate the entire ice column (Bassis et al., 2005; Hulbe et al., 2010).

\subsection{Implications}

Within satellite images of medium spatial resolution such as MODIS, surface features are widely observed in most parts of the Larsen C Ice Shelf (Glasser et al., 2009; Fig. 1), and in many ice shelves elsewhere (e.g. Crabtree and Doake, 1980; Fahnestock et al., 2000). If all of these features correspond to basal crevasses (penetrating up to two thirds of the ice column) or rifts (penetrating the entire ice column), rather than surface crevasses (with limited penetration), then collectively they may be significant. Such abundant faults within ice shelves will increase the surface area available for the exchange of mass and heat with the ocean cavity and may have a substantial influence on stresses within the shelf.

\section{Crevasse penetration height modelling}

\subsection{Introduction}

A better understanding of where basal crevasses may form, and how far they are likely to penetrate is desirable for future prediction of ice shelf dynamics and stability. A number of approaches have previously been used to model basal crevasse penetration heights (e.g. Weertman, 1980; Jezek, 1984; van der Veen, 1998a; Rist et al., 1999, 2002; Nick et al., 2010). The approach adopted by Nick et al. (2010) assumes that the crevasses are closely-spaced and uses the zero stress criterion in which the balance of tensile stress, water pressure and lithostatic stress is considered. We found this method to significantly under-predict the penetration heights of both series of crevasses investigated in this study, possibly because they are more than $1 \mathrm{~km}$ apart (over three times the ice thickness) and therefore cannot be considered to be "close". Here we choose to test the LEFM (linear elastic fracture mechanics) approach (Rist et al., 2002) in its abilities to predict penetration depths because it is well established for crevasse propagation in ice. Since crevasses are known to propagate very rapidly under high tensile strain rates $(\mathrm{Pa}-$ terson, 1994; Scott et al., 2010), it is often appropriate to model ice as an elastic solid, despite its longer-term viscous properties (Nye, 1970). The LEFM approach has been used to demonstrate that basal crevasses can form readily in ice shelves, but rarely on previous occasions to compare measured to predicted penetration heights (e.g. Rist et al., 2002), probably because of the difficulty in finding crevasse observations coincident with known stress fields (van der Veen, 1998a).

We model crevasse penetration height with the LEFM approach for all four crevasses for which the penetration height of the crevasse tip could be estimated from the GPR data. Here we have suitable in-situ measurements of crevasse penetration heights and ice densities, and we calculate the depthdependent stress from observed surface strain rates using manual feature tracking of Landsat satellite images. Although the crevasses will have been advected downflow since their initiation, we choose to compare measured to modelled penetration heights using the tensile stress calculated at their present locations. Here, since the ice continues to accelerate towards the calving margin, the tensile stress is at a maximum for the crevasse history. It is possible that open basal crevasses maintain a crack tip sharp enough to continue to propagate (aided by tidal flexure) as they are advected downflow and thereby would be able to adapt to the current stress environment. Choosing to use the present location strain rates will thus make the modelled crevasses penetration heights an upper bound.

The model implementation follows Rist et al. (2002) and is briefly described here. To calculate basal crevasse penetration depth we consider the balance of total stresses across a crevasse (which include longitudinal and lithostatic stresses) 
and the water pressure within it. Longitudinal stresses are derived from the satellite-derived strain rates using Glen's constitutive flow relation (e.g. Paterson, 1994) and are dependent on depth through the relationship to temperature. Following Sandhäger et al. (2005), the temperature is approximated by the function:

$T(a)=\left(T_{\mathrm{S}}-T_{\mathrm{b}}\right) \cdot\left(\frac{a}{H}\right)^{\frac{1}{3}}+T_{\mathrm{b}}$

where $T=$ Temperature, $a$ is the position in the ice column, $T_{\mathrm{S}}$ is surface temperature, $T_{\mathrm{b}}$ is basal temperature, and $\mathrm{H}$ is ice thickness. The surface temperature we used is the annual mean for Larsen C Ice Shelf at $-16^{\circ} \mathrm{C}$ and the basal temperature is $-2^{\circ} \mathrm{C}$, or approximately the freezing point of sea water. This approach gives a temperature profile with a steep gradient at the base typical of a shelf undergoing basal melting (Paterson, 1994; Shepherd et al., 2003). Ice thickness is taken from the field measurements (Figs. 3, 4) and the calculation of lithostatic stress requires a density profile through the ice column which is derived from seismic measurements in the field (Jansen et al., 2010).

Following Fett et al. (1990), we calculate the stress intensity factor for the geometry of an edge crack within a plate of finite thickness, an approach which is valid until the ratio between ice thickness and crevasse height is smaller than 0.9. The calculation is complicated by the fact that temperature and density vary within the ice column in such a way that the stress balance is nonlinear with depth. The numerical approach approximates the non-linear stress balance with a polynomial from which a solution for the stress intensity factor can be calculated (Rist et al., 2002).

The process of elastic linear fracturing is illustrated in Fig. 6 for the four basal crevasses discussed. Once the critical stress intensity of $1.5 \times 10^{5} \mathrm{~Pa} \mathrm{~m}^{0.5}$ (Rist et al., 2002) is exceeded, a crevasse can start to propagate upwards. At first the stress intensity factor at the crevasse tip begins to increase with height, giving even more impetus to the fracture. Eventually it decreases until it returns once again to the critical stress intensity, causing the crevasses tip to stop propagating. The penetration height at which this happens is dependent on the strain rate and ice thickness, and might therefore differ between the crevasses. Figure 6 highlights the fact that longitudinal stress is a stronger controlling factor than ice thickness in this part of the shelf (Series 2 crevasses are predicted to be deeper than Series 1 crevasses). Table 1 gives values for crevasse penetration heights modelled using this approach, along with their estimates from GPR data.

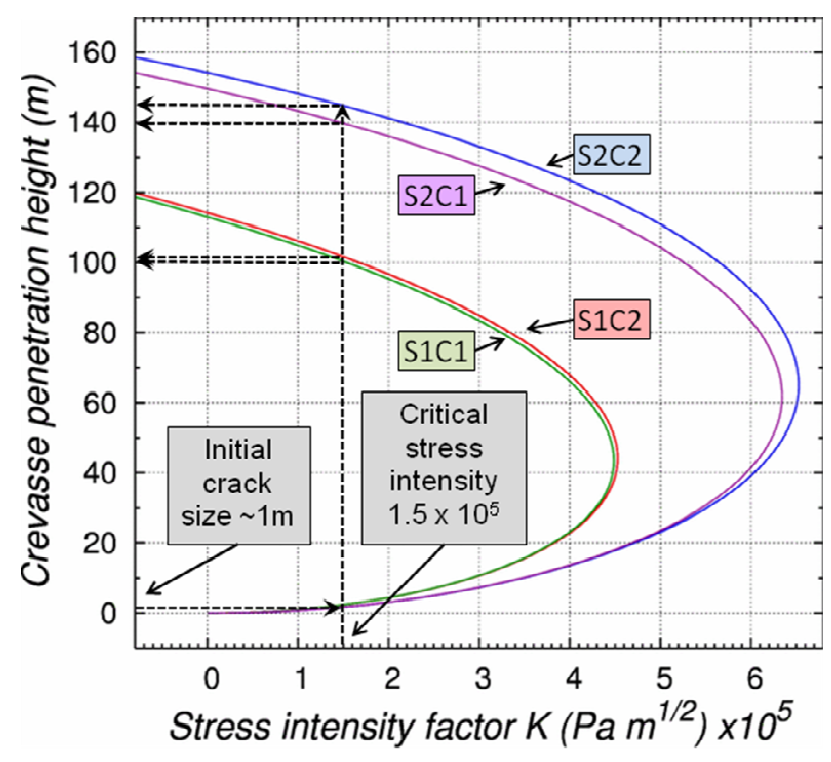

Fig. 6. Relationships between stress intensity and crevasses penetration height for the four crevasses studied in detail. Once initiated from a flaw of $\sim 1 \mathrm{~m}$, a crevasse grows until the stress intensity returns to the critical value, and its height is determined by the ice thickness, density and deformation rate.

\subsection{Discussion of LEFM model results}

The LEFM approach underestimates the penetration height of all four basal crevasses, even though these predictions are an upper bound on the assumption that the crevasses may have adapted to the present minimum backstress conditions (Table 1). Nevertheless, the modelled height of S1C1 and S1C2 in crevasse Series 1 (Fig. 2a) are within $10-20 \%$ of their measured values. Given the combined errors in model parameters and field measurements, we infer that LEFM may be a good predictor of crevasse penetration height for these crevasses.

The penetration heights of $\mathrm{C} 2 \mathrm{C} 1$ and $\mathrm{C} 2 \mathrm{C} 2$ in crevasse Series 2 (Fig. 2b) are underestimated using LEFM by between 20 and $35 \%$, a discrepancy which falls outside even our most conservative estimates of error. A likely explanation for this discrepancy lies in the nature of stresses in this part of the shelf. Crevasses S2C1 and S2C2 appear to be en echelon features which form under significant shear stresses that rotate the central part to form the crevasse into a sigmoid shape (Benn and Evans, 2010). Shear stresses at this location calculated from flow model results (Jansen et al., 2010) are of the same order of magnitude as the longitudinal stresses. The modelling approach we have taken considers only mode I stresses and does not take into account such shear processes, which may act to further propagate basal crevasses in regions with a non-simple stress regime. 


\section{Conclusions}

Using geophysical survey and remote sensing on the Larsen $\mathrm{C}$ Ice Shelf, we have demonstrated that a group of features visible in MODIS images, and previously described simply as "crevasses", are completely explained as the surface expressions of basal crevasses in the form of surface troughs. We have shown that such features cannot be surface crevasses because they would not be resolved at the spatial resolution of MODIS. We have shown that it is possible for basal crevasses to be generated as a result of stresses well downstream of the grounding line and that they can sometimes penetrate as much as two thirds of the ice column.

Having surveyed and modelled four basal crevasses in Larsen C Ice Shelf, we find that the LEFM approach is an appropriate predictor of penetration height where stresses are predominantly tensile, but can significantly underestimate penetration height in regions affected by shear. The surface trough depth for the crevasses we measured is less than might be expected through hydrostatic equilibrium, most likely because of preferential surface accumulation within them, marine ice accretion in the basal crevasses below or stress bridging from the surrounding ice.

Surface features are common in MODIS images of the Larsen $\mathrm{C}$ and other ice shelves. By extrapolation, these features must either be the surface expressions of basal crevasses (which can penetrate a significant proportion of the ice column) or rifts that have propagated laterally (penetrating the entire ice column) rather than surface crevasses (which penetrate relatively small distances through the ice). Although they have received little attention to date, such abundant and sometimes deep faults within ice shelves have implications for both their thermodynamic and structural properties. By increasing the area of interface between ice and water, they may enhance heat exchange with the ocean deep inside the shelf where the ice would otherwise be well insulated from external sources of heat.

Through their potential to be initiated mid-shelf, and by modifying the bulk mechanical properties of the ice, basal crevasses may play an important part in ice shelf stability. Penetration heights may be enhanced by surface densification as the climate warms, and it is possible that they have contributed to the break-up of ice shelves on the Antarctic Peninsula (Holland et al., 2011). To assess the current stability and predict the future longevity of ice shelves, the abundance and penetration height of basal crevasses should be considered within ice shelf models.

Acknowledgements. This project was funded by the UK Natural Environment Research Council through the Antarctic Funding Initiative (AFI) (NE/E012914/1). GPR and GPS equipment was kindly loaned by the NERC Geophysical Equipment Facility (GEF-905). We would particularly like to thank Neil Glasser for sharing DISP data with us, and Catrin Thomas for assistance during the field campaign.

Edited by: A. Klein

\section{References}

Barrett, B., Murray, T., and Clark, R.: Errors in radar CMP velocity estimates due to survey geometry, and their implication for ice water content estimation, J. Environ. Eng. Geophys., 12, 101111, doi:10.2113/JEEG12.1.101, 2007.

Bassis, J. N., Coleman, R., Fricker, H. A., and Minster, J. B.: Episodic propagation of a rift on the Amery Ice Shelf, East Antarctica, Geophys. Res. Lett., 32, L06502, doi:10.1029/2004GL022048, 2005.

Benn, D. I. and Evans D. J. A.: Glaciers and Glaciation, 2nd Ed., Hodder Education, London, 2010.

Christoffersen, P., Piotrowski, J. A., Nicolaj, K., and Larsen, N. K.: Basal processes beneath an Arctic glacier and their geomorphic imprint after a surge, Elisebreen, Svalbard, Quaternary Res., 64, 125-137, 2005.

Crabtree, R. D. and Doake, C. S. M.: Flow lines on Antarctic ice shelves, Polar Rec., 20, 31-37, doi:10.1017/S0032247400002898, 1980.

Fahnestock, M. A., Scambos, T. A., Bindschadler, R. A., and Kvaran, G.: A millennium of variable ice flow recorded by the Ross Ice Shelf, Antarctica, J. Glaciol., 46, 652-664, doi:10.3189/172756500781832693, 2000.

Fett, T., Munz, D., and Neumann, J.: Local stress intensity factors for surface cracks in plates under power-shaped stress distributions, Eng. Fract. Mech., 36, 647-651, 1990.

Glasser, N. F. and Scambos, T. A: A structural glaciological analysis of the 2002 Larsen B ice-shelf collapse, J. Glaciol., 54, 3-16, doi:10.3189/002214308784409017, 2008.

Glasser, N. F., Kulessa, B., Luckman, A., Jansen, D., King, E. C., Sammonds, P. R., Scambos, T. A., and Jezek, K. C.: Surface structure and stability of the Larsen C Ice Shelf, Antarctic Peninsula, J. Glaciol., 55, 400-410, doi:10.3189/002214309788816597, 2009.

Haran, T., Bohlander, J., Scambos, T., Painter, T., and Fahnestock, M.: MODIS mosaic of Antarctica (MOA) image map, Boulder, Colorado USA: National Snow and Ice Data Center, Digital media, 2006.

Harper, J. T., Bradford, J. H., Humphrey, N. F., and Meierbachtol, T. W.: Vertical extension of the subglacial drainage system into basal crevasses, Nature, 467, 579-582, doi:10.1038/nature09398, 2010.

Hellmer, H. H. and Jacobs, S. S.: Ocean interactions with the base of Amery Ice Shelf, Antarctica, J. Geophys. Res., 97, 19251931, doi:10.1029/92JC01856, 1992.

Holland, P. R., Corr, H. F. J., Vaughan, D. G., Jenkins, A., and Skvarca, P.: Marine ice in Larsen Ice Shelf, Geophys. Res. Lett., 36, L11604, doi:10.1029/2009GL038162, 2009.

Holland, P. R., Corr, H. F. J., Pritchard, H. D., Vaughan, D. G., Arthern, R. J., Jenkins, A., and Tedesco, M.: The air content of Larsen ice shelf, Geophys. Res. Lett., 38, L10503, doi:10.1029/2011GL047245, 2011.

Hulbe, C. L., LeDoux, C., and Cruikshank, K.: Propagation of long fractures in the Ronne Ice Shelf, Antarctica, investigated using a numerical model of fracture propagation, J. Glaciol., 56, 459472, doi:10.3189/002214310792447743, 2010.

Humbert, A. and Steinhage, D.: The evolution of the western rift area of the Fimbul Ice Shelf, Antarctica, The Cryosphere, 5, 931944, doi:10.5194/tc-5-931-2011, 2011. 
Jansen, D., Kulessa, B., Sammonds, P. R, Luckman, A., King, E. C., and Glasser, N. F.: Present stability of the Larsen C Ice Shelf, Antarctic Peninsula, J. Glaciol., 56, 593-600, 2010.

Jezek, K. C.: A modified theory of bottom crevasses used as a means for measuring the buttressing effect of ice shelves on inland ice sheets, J. Geophys. Res., 89, 1925-1931, doi:10.1029/JB089iB03p01925, 1994.

Jezek, K. C. and Bentley, C. R.: Field studies of bottom crevasses in the Ross Ice Shelf, Antarctica, J. Glaciol., 29, 118-126, 1983.

Jenkins, A. and Doake, C. S. M.: Ice-ocean interaction on Ronne Ice Shelf, Antarctica, J. Geophys. Res., 96, 791-813, doi:10.1029/90JC01952, 1991.

Jezek, K. C., Bentley, C. R., and Clough, J. W.: Electromagnetic sounding of bottom crevasses on the Ross Ice Shelf, Antarctica, J. Glaciol., 24, 321-330, 1979.

Khazendar, A. and Jenkins, A.: A model of marine ice formation within Antarctic ice shelf rifts, J. Geophys. Res., 108, 3235, doi:10.1029/2002JC001673, 2003.

McGrath, D., Steffen, K., Scambos, T., Rajaram, H., Casassa, G., and Rodriguez, J.: Basal crevasses and associated surface crevassing on the Larsen C Ice Shelf, Antarctica and their role in ice shelf instability, Ann. Glaciol., 53, in press, 2012.

Nick, F. M., van der Veen, V. A., and Benn, D. I.: A physically based calving model applied to marine outlet glaciers and implications for the glacier dynamics, J. Glaciol., 56, 781-794, doi:10.3189/002214310794457344, 2010.

Nye, J. F.: Glacier sliding without cavitation in a linear viscous approximation, P. R. Soc. Lond. A. Ma., 315, 381-403, doi:10.1098/rspa.1970.0050, 1970.

Paterson, W. S. B.: The Physics of Glaciers3rd Edition, Reed Educational and Professional Publishing, Oxford, 1994.

Peters, M. E., Blankenship, D. D., Smith, D. E., Holt, J. W., and Kempf, S. D.: The distribution and classification of bottom crevasses from radar sounding of a large tabular iceberg, IEEE Geosci. Remote Sens., 4, 142-146, doi:10.1109/LGRS.2006.887057, 2007

Rist, M. A., Sammonds, P. R., Murrell, S. A. F., Meredith, P. G., Doake, C. S. M., Oerter, H., and Matsuki, K.: Experimental and theoretical fracture mechanics applied to Antarctic ice fracture and surface crevassing, J. Geophys. Res., 104, 2973-2987, doi:10.1029/1998JB900026, 1999.
Rist, M. A., Sammonds, P. R., Oerter, H., and Doake, C. S. M.: Fracture of Antarctic shelf ice, J. Geophys. Res., 107, 2002, doi:10.1029/2000JB000058, 2002.

Sandhäger, H., Rack, W., and Jansen, D.: Model investigations of Larsen B Ice Shelf dynamics prior to the breakup, Forum for Research into Ice Shelf Processes (FRISP), Report, 16, 5-12, Bjerknes Cent. For Clim. Res., Bergen, Norway, 2005.

Scott, J. B. T., Smith, A. M., Bingham, R. G., and Vaughan, D. G.: Crevasses triggered on pine island glacier, west Antarctica, by drilling through an exceptional melt layer, Ann. Glaciol., 51, 65-70, doi:10.3189/172756410791392763, 2010.

Shabtaie, S. and Bentley, C. R.: Tabular icebergs: implications from geophysical studies of ice shelves, J. Glaciol., 28, 413-430, 1982.

Shepherd, A., Wingham, D., Payne, T., and Skvarca, P.: Larsen Ice Shelf has progressively thinned, Science, 302, 856-859, doi:10.1126/science.1089768, 2003.

Skvarca, P.: Changes and surface features of the Larsen Ice Shelf, Antarctica, derived from Landsat and kosmos mosaics, Ann. Glaciol., 20, 6-12, 1994.

Thomas, R. H.: The creep of ice shelves: Theory, J. Glaciol., 12, 45-53, 1973.

van den Broeke, M.: Strong surface melting preceded collapse of Antarctic Peninsula Ice Shelf, Geophys. Res. Lett., 32, L12815, doi:10.1029/2005GL023247, 2005.

van der Veen, C.: Fracture mechanics approach to penetration of bottom crevasses on glaciers, Cold Reg. Sci. Technol., 27, 213223, doi:10.1016/S0165-232X(98)00006-8, 1998a.

van der Veen, C.: Fracture mechanics approach to penetration of surface crevasses on glaciers, Cold Reg. Sci. Technol., 27, 3147, doi:10.1016/S0165-232X(97)00022-0, 1998b.

Weertman, J.: Bottom crevasses, J. Glaciol., 25, 185-188, 1980.

Woodward, J. and Burke, M. J.: Applications of ground-penetrating radar to glacial and frozen materials, J. Environ. Eng. Geophys., 12, 69-85, doi:10.2113/JEEG12.1.69, 2007. 